\title{
A TENSÃO ENTRE O PRIVADO E O PÚBLICO NA TRAGÉDIA HIPÓLITO, DE EURÍPIDES
}

\author{
Fernando Crespim Zorrer da Silva \\ UFES
}

RESUMO: Discutir o 'privado' e o 'público' em uma tragédia grega demanda que se preocupe com diversas questões, como, por exemplo, a posição da mulher e a do homem na casa, a atuação masculina na pólis e até mesmo a presença dos deuses nas relaçōes humanas. A tragédia Hipólito, de Eurípides, nos proporciona um debate sobre os limites entre o 'privado' e o 'público', ressaltando como o homem e a mulher oscilam nesse caminho de conhecimento do mundo. Por peculiaridade de toda a cena dramática, a narrativa ocorre quando Teseu está ausente de casa sem que se saiba onde está e nem há o conhecimento se está vivo; é o momento da desintegração da sua família e consequentemente o limite do privado e do público das personagens se transforma.

PALAVRAS-CHAVE: Hipólito; Fedra; Euríides.

\section{THE CLASH BETWEEN PRIVATE AND PUBLIC IN THE EURIPIDEAN TRAGEDY 'HIPPOLYTUS'}

\begin{abstract}
Discussing the "private" and the "public" in a Greek tragedy requires addressing different issues, such as the male and female roles in the household, the male activities in the polis, and even the presence of gods in human relationships. Euripides' Hippolytus provides us with a debate about the boundaries between the "private" and the "public", emphasizing different vantage points from which men and women see the world. A peculiar aspect of the whole dramatic scene is that the narrative takes place when Theseus is far from home and, therefore, one does not know where he is or whether he is alive; that is the moment of disintegration of his family and, consequently, the boundaries between the private and the public are reshaped.
\end{abstract}

KEYWORDS: Hippolytus; Phaedra; Euripides.

Fernando Crespim Zorrer da Silva é doutor em Letras Clássicas pelo Programa de Pós-Graduação em Letras Clássicas do Departamento de Letras Clássicas e Vernáculas da Faculdade de Filosofia, Letras e Ciências Humanas da Universidade de São Paulo. Atualmente é bolsista de pós-doutorado na Universidade Federal do Espírito Santo. 


\title{
A TENSÃO ENTRE O PRIVADO E O PÚBLICO NA TRAGÉDIA 'HIPÓLITO’ DE EURÍPIDES
}

\author{
Fernando Crespim Zorrer da Silva
}

A tragédia Hipólito de Eurípides foi apresentada em 428 a. C., justamente alguns anos antes do início da Guerra do Peloponeso. ${ }^{1}$ Nessa obra se observa a deusa Afrodite irada com o jovem Hipólito por este tê-la ofendido. A divindade, para se vingar, faz com que Fedra, madrasta de Hipólito, se apaixone pelo enteado. Após uma série de mal-entendidos, como o temor de ser delatada e a má orientação de sua aia, a esposa de Teseu acusa o jovem de tê-la tocado, deixando uma carta com a acusação e se suicida. Teseu, pai de Hipólito, retorna de uma viagem, se informa do ocorrido e amaldiçoa o seu próprio filho, que morre ao ser perseguido por um touro. No êxodo da peça, há o relato do que sucedeu por parte da deusa Ártemis bem como há a reconciliação entre pai e filho. Por fim, são instituídos cultos na cidade para que para que o ocorrido entre Fedra e Hipólito não seja esquecido.

$\mathrm{Na}$ verdade, esta peça de Eurípides apresenta outros binômios que são discutidos, como interno-externo, sabedoria-ignorância, natureza-lei e privado-público que perpassam todo o drama, mesmo após a morte de Fedra. ${ }^{2}$ Nessa equação dos conceitos, vale frisar que este drama constitui uma segunda versão do mesmo mito pelo autor, porque a primeira, chamada de Hipólito encoberto, da qual restaram poucos fragmentos, foi mal recebida pelo público. Na literatura mundial, é um dos poucos casos nos quais um autor reescreve um novo texto tentando resolver o mal-entendido de uma obra anterior. O motivo de tal reação do público teria sido o ato de Fedra que revelava diretamente o seu desejo amoroso ao seu enteado. Tal cena seria retomada nas peças Fedra, tanto de Sêneca como de Racine, por exemplo. A questão, aqui, é a ruptura drástica, como veremos, a seguir, do desejo da rainha, do seu universo privado, que é realizada por si mesma diretamente ao seu objeto de desejo, diferentemente do que sucede na segunda versão

\footnotetext{
${ }^{1}$ EURIPIDES. Children of Heracles. Hippolytus. Andromache. Hecuba. Trans. David Kovacs. London: Harvard University Press, 1995. v. 2.

2 SEGAL, Charles. Shame and purity in Euripides' Hippolytus. Hermes, v. 98, p. 278-99; 283$287,1970$.
} 
da tragédia que estamos analisando. Tal ato da rainha provocou o escândalo, visto que não houve um processo gradual da revelação do seu desejo; resultou na respectiva exposição de sua paixão por Hipólito, a qual gerou o desastre na família de Teseu.

A peça Hipólito, desde o seu início, se movimenta do mundo físico de Fedra em direção ao ritual público e da consciência da pólis. ${ }^{3}$ Trata-se de uma locomoção do universo da mulher ao homem, do universo privado ao público. A paixão da rainha é revelada lentamente; neste caso, a passagem do privado para o público está associada ao seu segredo que se espalha até que toda a cidade de Trezena tenha conhecimento do ocorrido. A dor de Teseu pela perda de seu filho revela a situação dramática na qual está envolvido, conforme a sua proclamação, no final da peça: “Ó famoso território de Erecteu e de Palas, / que homem perdereis! Sou desgraçado, / pois me lembrarei muito, Cípris, dos teus males!", v. 1459-1461. ${ }^{4}$

Conforme o prólogo, tendo se aproximado de Hipólito, "Fedra, viu-o e ficou possuída em seu coração, / pelos meus desígnios, por uma terrível paixão", v. 27-28, como proclama Afrodite sendo, deste modo, a responsável direta por tal ato. Assim, a esposa de Teseu está em um processo bastante complexo de tomada de decisões. Ainda, a referida deusa reforça que foi atacada pelo filho de Teseu, pois o personagem a julga o pior dos Numes, e, como observa Cípris, ele é o único dos cidadãos de Trezena que age de tal modo, conforme os versos 12-14, "Hipólito, instruído pelo casto Piteu, / único dentre os cidadãos desta terra de Trezena, / diz que sou o pior dos Numes". A posição de Hipólito, ao divulgar a sua preferência religiosa, é justamente o que diz respeito a ser público: “... tudo o que vem a público pode ser visto e ouvido por todos e tem a maior divulgação possível." ${ }^{5}$

Além disso, outra questão importante é que Hipólito, mesmo que não tenha interesse pelos assuntos sexuais e pelo casamento, mesmo sendo um indivíduo casto, torna pública a sua opinião contra uma divindade, divulgando de uma maneira que ela agora já sabe; Afrodite não ficou examinando os pensamentos do jovem, mas esse tornou público algo que jamais deveria ter proclamado: proferiu terríveis palavras contra ela. A equação entre pensamento e fala é, aqui, decisiva e orientará os passos não só de Hipólito, pelo fato de

\footnotetext{
${ }^{3}$ Idem, Theatre, ritual and commemoration in Euripides'Hippolytus. Ramus, v. 17, p. 52-74, 1988.

4 Todas as traduções deste artigo foram realizadas pelo autor.

5 ARENDT, Hanna. A condição humana. Trad. Roberto Raposo. 10. ed. Rio de Janeiro: Forense Universitária, 2007, p. 59.
} 
Afrodite saber o que ele julga a seu respeito, como também de Fedra, que não conseguiu manter os seus pensamentos na esfera do privado e, por diversos motivos, como veremos, a sua paixão se tornará pública paulatinamente.

Ainda sobre a temática entre Hipólito e Afrodite, essa é acentuada no final do prólogo, pois um servo questiona o jovem pela sua atitude de manter distância de Afrodite e esse se esquiva mais uma vez, conforme os versos 88105, ou seja, há uma comprovação das palavras de Afrodite mediante o próprio Hipólito que mantém tal divindade afastada de seu convívio. Trata-se de um recurso para salientar que as palavras de Afrodite são realmente verdadeiras; não é um embuste da divindade e o que importa é que, com as palavras de Hipólito, a rejeição de Afrodite também se manifesta, efetivamente, no plano dos mortais mediante um diálogo que ocorre na esfera pública.

O comportamento de Hipólito já é conhecido como diferenciado entre as mulheres que fazem parte da casa de Teseu e, mais do que nunca, uma frase de Fedra acentua tal perspectiva, pois essa afirma, no primeiro episódio, v. 351: "Quem quer que este seja, o filho da amazona ...". Eis um indicativo do problema da conduta pública do filho de Teseu. Quem ele é? Aos olhos de Fedra, há dúvidas sobre a sua personalidade. Georges Devereux ${ }^{6}$ vai mais longe na análise, quando afirma que Eurípides observou um tipo de indivíduo que emergia na sua sociedade, um desajustado que surge nos períodos marcados por uma severa crise. Mesmo com um comportamento diferenciado em relação à sexualidade, esse jovem julga que, por ser um ser predileto da deusa Ártemis, essa o protege em todas as esferas no que inclui tanto o privado como o público; no entanto, como menciona Ártemis no êxodo, ela não pode salvá-lo, visto que não é possível se intrometer nos assuntos de Cípris, v. 13281334 ,

\footnotetext{
Esta é a lei entre os deuses: ninguém quer se opor ao desejo do outro, no entanto sempre nos afastamos disso.

Depois, saiba que, se não temesse a Zeus, eu não viria envergonhada nessa condição ao permitir que o homem mais amado de todos os mortais morresse.
}

Aquilo que é dito publicamente causa graves problemas a Hipólito; vale observar que Afrodite não está caçando seres castos mas, justamente,

${ }^{6}$ DEVEREUX, George. The character of the euripidean Hippolytos: an ethno-psychoanalytical study. California: Scholar Press, 1985, p. 17. [Studies in the humanities]. 
indivíduos que a ofendem, pois se justificaria que ela não fizesse o mesmo com Piteu, v. 11, que é casto e é mencionado por ela no prólogo. As palavras tornadas públicas a ferem e vão além do bom senso. De fato, os deuses estão presentes na esfera pública e, se o seu nome é invocado, eles sabem quem os invocou, nomeou, criticou, enfim, basta que surja o nome da divindade, esta pode entrar em ação ou não. Na llíada, por exemplo, no canto, VI, versos 86 ss, um grupo de anciãs acorre a produzir uma roupa especial à deusa Palas Atena, para que essa fosse favorável aos troianos, porém essa não lhes concede a graça solicitada.

$\mathrm{Na}$ verdade, a ironia se faz também presente, conforme assinala Charles Segal,7 pois se a instituição do casamento foi rejeitada por ele, Hipólito, conforme o verso 14, "Recusa o amor e não toca no casamento", contudo perpetuará o seu nome na cidade, com a instituição de rituais do casamento após a sua morte, conforme os versos 1423-30:

\footnotetext{
E a ti, ó miserável, no lugar destes males, eu te darei as maiores honras na cidade de Trezena.

As jovens solteiras, antes do casamento, cortarão os cabelos para ti; por um longo tempo, colhendo o maior sofrimento de suas lágrimas. A prática do canto das virgens sempre contigo estará preocupada; não caindo no esquecimento e nem a paixão de Fedra por ti será silenciada.
}

Neste caso, o desejo privado do filho de Teseu, ao se manter afastado da comunidade, ao não se envolver com as mulheres e nem com o sexo, sofreu uma transformação no que resultou na instituição de rituais na cidade de Trezena e o seu nome estará associado a eles. Ao se afastar do âmbito público da cidade, com a sua morte, terminou por fazer parte dela, de maneira forçada, sem que pudesse opinar ou tomar alguma atitude contrária. Hipólito não se casa, mas a sua morte manterá um vínculo público com o casamento. Desta forma, o nome do personagem também estará associado justamente a um grupo social, oprimido, com o qual demonstra não manter contato, que são as mulheres. Outro aspecto importante é que o sexo constitui um dos grandes momentos do relacionamento afetivo entre homem e mulher e do qual o personagem se afasta, conforme o relato de Afrodite, e a própria confissão que o jovem realizou diante do seu pai também estará indiretamente relacionada ao seu nome, conforme os versos 1002-1006:

\footnotetext{
7 SEGAL, Charles. Theatre, ritual and commemoration in Euripides'Hippolytus, op. cit., p. 55.
} 


\begin{abstract}
De uma coisa estou intocado, a qual julgas que me apanhaste: até este dia, o meu corpo é casto quanto ao sexo. Não conheço esta prática exceto ao ouvir um discurso e contemplar pinturas. Nem isto examino com disposição, pois tenho a alma virgem.
\end{abstract}

Se a intenção era se afastar da pólis, como assinala o seu comportamento, pois permanece com a deusa caçando as feras, agora manterá um vínculo com um ritual público no qual as mulheres, das quais se afastou, se farão presentes, como também de Cípris, a qual feriu com as palavras e foi atacado por essa divindade, e com essa estará realmente vinculado. Além disso, cabe frisar que quem institui tal ritual nada mais é que Ártemis. Por que a divindade que padece com a perda de Hipólito realizou algo que parece ultrajá-lo? Hipólito deixou de lado, o ciclo da vida, ao renunciar ao casamento e ao sexo, além de ter insultado uma deusa. A própria Ártemis, apesar de sua castidade, mantém um vínculo intenso com o sexo, pois ela é invocada na ajuda no parto (essa deusa também é a deusa do nascimento), ${ }^{8}$ conforme o coro proclama nos versos 166-169:

\footnotetext{
Mas invoquei a protetora dos partos, a celestial dos arcos, Ártemis, sempre invejavelmente, frequenta-me com a anuência dos deuses.
}

Já o universo de Fedra é cercado por mulheres, como o próprio coro demonstra no párodo sugerindo uma série de possibilidades pelas quais explicariam a alteração drástica do comportamento da rainha. Neste momento, o privado concerne aos que permanecem no palácio, ao lado de Fedra, que correspondem, essencialmente, ao coro e à aia. Hipólito, como é demonstrado ao longo da peça, mantém-se afastado dali e não se ocupa dos assuntos da pólis e nem do palácio de seu pai. O párodo abarcará o privado e o público, o geral e o particular, o indivíduo e o dinástico. ${ }^{9}$ Em resumo, o coro, representado por um grupo de mulheres, questionará se Fedra tem algum problema com uma divindade (deixou de fazer oferendas ou está possuída), se Teseu está tendo relações sexuais com outra mulher, se veio alguma

\footnotetext{
${ }^{8}$ BURKERT, Walter. Religião grega na época clássica e arcaica. Trad. M. J. Simões Loureiro. Lisboa: Fundação Calouste Gulbenkian, 1993, p. 299.

9 LUSCHNIG, Cecelia A. E. Time holds the mirror: a study of knowledge in Euripides' Hippolytus. Nova York: E. J. Brill, 1988, p. 69.
} 
notícia de Creta, sua terra natal, ou ainda, até se está grávida. No rol dessas possibilidades, observa-se que o coro, após falar de assuntos genéricos, altera para opinar a respeito da vida privada de Fedra e até compara a si mesmo, o coro, com a rainha. ${ }^{10}$

O que aconteceu a Fedra por estar desse modo? Eis uma questão que é repetida na peça até chegarmos à revelação do segredo. Há uma diferença quanto ao conhecimento da trama, pois, no prólogo, Afrodite já nos informou o que está acontecendo; o espectador sabe o que sucede, mas não os personagens que fazem parte do drama. Assim, demarca-se amplamente a oposição, visto que o dramaturgo salienta o binômio privado versus público, fato comum observado também em outras tragédias. Lentamente se observa que tudo aquilo que envolve a paixão da rainha é revelado; aquilo que é oculto e está fechado no ambiente privado perde esse caráter e, na sequência, ocorrem atos que culminarão nas mortes tanto da rainha como do enteado.

Também esse universo que abarca o privado quanto à Fedra, isto é, quanto ao seu íntimo, é vedado. Sabe-se que algo está ocorrendo no interior dessa personagem. Conforme foi mencionado no párodo, Fedra está há três dias em jejum. No universo grego, personagens que estão passando por graves momentos emocionais não mais comem, como, por exemplo, Príamo e Aquiles, conforme Ilíada, canto XIX, v. 346, pois sofrem pelas perdas, respectivamente, do filho e do amigo; Ájax, o da peça homônima do dramaturgo Sófocles, não deseja comer devido ao sofrimento que envolve toda a situação de vergonha da qual está padecendo, v. 324-32511; aqui, Fedra sofre emocionalmente ao reprimir um desejo sexual. Também, ao mesmo tempo, padece pela vergonha e pelo medo por aquilo que está passando, isto é, a primeira por fazer algo que socialmente não é aceito, o segundo, porque alguém pode saber. O que se articula contra Fedra, contra a preservação do seu estado privado, no que abarca os segredos de seus pensamentos e de seus desejos, é, fundamentalmente, a fraqueza do seu corpo que contribui, de modo decisivo, na revelação do seu segredo. Hannah Arendt ${ }^{12}$ esclarece que a dor física é a experiência mais privada e ao mesmo tempo que se tem mais dificuldade para se comunicar aos outros e tal análise ajuda a entender a demora na revelação do segredo da esposa de Teseu.

\footnotetext{
10 Ibidem.

${ }^{11}$ KARYDAS, Helen Pournara. Eurykleia and her successors. Female figures of authority in greek poetics. Lanham: Rowman \& Littlefield Publishers, 1998, p. 96.

12 ARENDT, Hanna. A condição humana, op. cit., 2007, p. 60.
} 
Após a preocupação do coro ser revelada no párodo, segue o primeiro episódio. Em primeiro lugar, a rainha abrirá os seus profundos segredos a uma mulher, contudo, ao mesmo tempo, revela para o espectador. ${ }^{13}$ Também Charles Segal destaca que, quando abre a cena, temos uma conversa íntima entre duas mulheres diante de um espectador da peça provavelmente masculino.

Corpo e mente estão sempre interligados e, se um dos dois não funciona bem, o resultado pode ser catastrófico. Consoante a essa situação, Fedra, que recusa em falar por que sofre e qual é o motivo que a transtorna, profere três falas com desejos que destoam completamente da imagem de uma senhora que habita um palácio, sendo ela esposa de Teseu, o grande herói ateniense, parceiro, em muitas aventuras, de Héracles. Em tais palavras da rainha, aparecem desejos de montar cavalos enéticos (cavalos oriundos da região norte do Mar Adriático), pegar água da fonte, deitar-se sobre a relva, sair em caçadas, conforme os versos 208-229; tais desejos não são compreendidos e são unicamente apontados como sendo uma 'fala insensata' por parte da nutriz, v. 232. Não há ali no palácio nenhum intérprete que consiga desmontar o discurso proclamado. Agora, segundo um olhar psicanalítico, como o de Georges Devereux, ${ }^{14}$ observam-se desejos sexuais velados, isto é, Fedra estava querendo substituir ela mesma por uma outra: Ártemis, pela qual Hipólito nutre um grande afeto. Além disso, com o jejum, tudo aquilo que se refere ao desejo da rainha, que recusa revelá-lo, começa a cair e esse é o estopim do que virá a seguir, mudando a vida completamente de todos. Aquilo que se refere ao âmbito dos pensamentos da rainha, passa, a seguir, a ser questionado por sua serva.

Neste quadro de sofrimento da rainha, é pertinente uma questão que envolve o lento descompasso que se verifica no seu universo privado: onde está Teseu, o homem da casa? A primeira questão a ser ponderada, sem seguirmos propriamente o início da peça, é a saída de Teseu, que é relatada no primeiro episódio, pela aia, v. 281, "Ele se encontra ausente deste país", não se sabe se retornará, visto que o texto (ao contrário da tragédia Fedra, de Racine, na qual se menciona que já se passaram seis meses desde a partida de Teseu) não esclarece quem seria o chefe da casa naquele momento. É uma situação complexa que remete à de Penélope, na Odisseia, de Homero, pois, ao que tudo

${ }^{13}$ SEGAL, Charles. Theatre, ritual and commemoration in Euripides'Hippolytus, op. cit., p. 56 ss.

${ }^{14}$ DEVEREUX, George. The character of the euripidean Hippolytos: an ethno-psychoanalytical, op. cit., p. 54 ss. 
indica, Telêmaco seria quem daria as ordens, cuidando do oikos (casa, palácio) na ausência do pai, porém, devido à pouca idade e associado à arrogância dos pretendentes, esses estão fazendo o que querem, pois comem, bebem e se envolvem sexualmente com as escravas, isto é, controlam quase tudo e até, de certo modo, a vida de Penélope.

Ao mesmo tempo, Hipólito mantém-se ausente, pois está a caçar com Ártemis, conforme os versos 17-18, "convivendo sempre com a virgem na floresta verde, / com os seus cães ágeis, extermina as bestas da terra". Esse jovem parece não ter muito interesse no poder político, pois, posteriormente dirá que quer ser o segundo na cidade, v. 1017, assim como Creonte, na peça Antígona de Sófocles, que se queda satisfeito ao ser o terceiro na cidade. ${ }^{15}$ Cada um desses personagens revela graus distintos de aspiração política, ainda mais que Creonte é ativo em termos políticos, ao passo que Hipólito expressa unicamente um comentário. Neste quadro que marca a ausência de Teseu, mesmo que se lembre que o mito é assim construído, revela uma falta de equilíbrio da presença de Teseu em sua casa bem como na cidade. O universo privado de Fedra queda esfacelado e a pessoa que poderia ter barrado tal processo não está presente. O fato mesmo de não se saber onde o esposo de Fedra está e quando retorna enfatiza os elos diminutos que possui com a sua cidade e com a sua família.

Além disso, a função de um homem na casa é comandá-la e, Hipólito, no segundo episódio, após ter proferido terríveis acusações, diante da aia de Fedra, contra as mulheres, assinala que se manterá longe de casa, conforme os versos 659-660, "Agora da casa afasto-me, enquanto ausente do país / estiver Teseu, e estarei com a boca calada". O que é isso? Ele não seria o chefe, enquanto o seu pai, Teseu, se mantém ausente? Esse personagem possui idade para governar o palácio de seu pai. Ele se esquiva de participar do elemento privado da casa e também do público, pois se afastou para um universo das bestas no qual desfruta com Ártemis. Se proclama que esperará o retorno de seu pai, será que ele sabe onde Teseu está e nada comenta com outros de sua casa? Dentro do palácio, naquele universo fechado, tudo parece estranho a Hipólito. É como se fosse um dissidente da pólis, pois dela não quer se aproximar, não querendo assumir uma posição pública. Se o filho de Teseu se afasta da casa, quem a está governando? Pela forma como se constrói a narrativa do drama, Fedra parece ser a personagem que coordena o oikos ao lado da serva, mas, no final, antes de cometer suicídio, deixa de lado a sua aia.

${ }^{15}$ NEWTON, Rick M. Hippolytus and the dating of Oedipus Tyrannos. Greek Roman and Byzantine Studies, v. 21, p. 5-22; p. 12, 1980. 
Deste modo, retomando o relato do primeiro episódio, em hipótese alguma a rainha pode estar agindo de outra forma; a gravidade da situação faz com que a nutriz empregue todos os recursos e estratagemas para descobrir o que há de errado. Ela se torna responsável pelo processo de ruptura que há entre o universo privado e o público. Graças aos seus atos, saberemos o segredo de Fedra. A gravidade dessa situação é que se trata não de seus pensamentos mas dos de Fedra. A serva possui um papel decisivo nesta tragédia; é significativo que a deusa Afrodite, que anuncia praticamente tudo o que se desenvolverá na tragédia, isto é, a paixão de Fedra por Hipólito, a morte da rainha, e a própria morte do filho por Teseu, não mencione a aia como fundamental para que a trama se desenvolva. Há muitas formas de se contar uma história. Aqui, o que importa, é que graças a essa personagem, o universo privado de Fedra é exposto; sem a referida personagem, o segredo da rainha teria permanecido intacto e se definharia paulatinamente como já estava fazendo.

O que se observa, segundo Charles Segal, ${ }^{16}$ é que a paixão se esconde e se move do ambiente fechado ao espaço privado e desse último ao teatral, além dos portões do palácio. A nutriz tenta, com diversos argumentos, persuadir a rainha a falar, mas, de repente, emprega um novo artifício que consiste em revelar os males aos homens, isto é, a um médico, v. 296, ou ao próprio marido que é mencionado, v. 281; neste caso, a esfera privada das mulheres seria invadida por um ser, de certo modo, estranho ao palácio que é um médico. A questão é que todo esse processo de racionalização, isto é, as inúmeras frases (conselhos, censuras, lamentos e outros artifícios) para que Fedra conte o que há de errado, é resolvido e substituído em uma única palavra: Hipólito. É por um acaso que tudo parece se desencadear e aquilo que envolvia o privado, isto é, o desejo da rainha é, de fato, expressado, mas não tão diretamente, pois Fedra, em nenhum momento na tragédia, pronuncia o nome Hipólito. Trata-se de uma palavra carregada de interditos (não proclame esse nome em público). Na realidade, quem faz o papel de trazer o que é privado ao público, justamente, é a serva que pronuncia o nome do filho de Teseu, conforme o verso 308. A reação de Fedra nada mais é do que expressar um desejo violento, pois roga que a criada a mate; eis o tamanho do temor do segredo, que está no âmbito privado, se alcançasse o público. Tal ordem corresponde à intensidade da culpa que a rainha sente e ao mesmo tempo à própria paixão. Assim, a perda do segredo que se situa no âmbito do privado agora é tão escandaloso e não deve ser trazido à esfera pública.

${ }^{16}$ SEGAL, Charles. Theatre, ritual and commemoration in Euripides'Hippolytus. Ramus, op. cit., p. 58. 
Após a revelação do segredo de Fedra, a sua privacidade continua a ser desmantelada. Tudo agora será tão rápido e terminará antes que o dia acabe. Vale lembrar que Afrodite, no prólogo, enfatiza que tudo será realizado em um único dia; na verdade, salvo algum fragmento que possa desmentir, todas as tragédias do dramaturgo grego sucedem ao longo de um único dia, de acordo com a posição de Aristóteles, Poética $1449 \mathrm{~b} 13 .{ }^{17}$

Há diversos níveis de privacidade na tragédia Hipólito e o tempo termina por revelar cada um deles em estágios diferentes. Em um primeiro momento, a privacidade envolve unicamente os pensamentos de Fedra, e todos ao seu redor desconfiam de algo, como demonstram a aia e o coro; é bom lembrar que tal nível não é violado por Cípris para saber o que Hipólito estava pensando. Depois Fedra começa a proclamar frases polêmicas e anormais para a situação, o que leva a um aumento na desconfiança das mulheres. Após os sucessivos ataques verbais da aia com o coro que ali também examina e questiona, a paixão da esposa de Teseu é revelada; o universo psíquico é conhecido agora; é o momento no qual pensamento e palavra falada se aproximam e rompem com a esfera privada do ser de Fedra. O maior temor da rainha se torna realidade: muitos já sabem, mesmo que sejam mulheres de sua confiança.

O que ocorre na sequência são revelações da intimidade tanto de Fedra como de Hipólito. A rainha faz um longo discurso falando de todos os estratagemas que buscou para destruir a paixão dentro de si mesma, como o silêncio e o emprego da razão. Tais explicações nos permitem observar como a rainha procurou se defender, não permitindo que ninguém soubesse do seu segredo, sem que a sua privacidade fosse violada. E no momento no qual a privacidade da rainha, isto é, o segredo mais íntimo que ela possuía foi revelado, a destruição começou a despontar no horizonte como uma possibilidade. Assim, a revelação daquilo que estava na esfera do privado para o público proporcionou a destruição da família de Teseu. Depois da primeira revelação do desejo de morte de Fedra, se entrelaçam alguns temas, como a paixão feminina, a fala humana, a opinião pública que se desenvolve entre os homens e de outros assuntos relacionados, v. 393-7 e 407-10. ${ }^{18}$ Esses se constituem, na essência, em alguns dos tópicos do longo discurso da rainha e nos permite inferir a sua habilidade em ponderar sobre diversos assuntos,

\footnotetext{
${ }^{17}$ LLOYD, Michael A. Euripides. In: DE JONG, Irene J. F.; NÜNLIST, René (Ed.). Time in Ancient Greek Literature: Studies in Ancient Greek Narrative. Boston: Koninklijke Brill NV, 2007, p. 293.

${ }^{18}$ SEGAL, Charles. Theatre, ritual and commemoration in Euripides'Hippolytus. Ramus, op. cit., p. 56.
} 
mesmo que esteja limitada a sua vida à casa e aos seus afazeres domésticos. A esposa de Teseu disserta tanto sobre o que padece em seu universo privado bem como sobre aquilo que sucede na sociedade e envolveria os atos dos homens no ambiente público.

Se os pensamentos de Fedra, que pertencem ao âmbito privado, tivessem sido comunicados a pessoas de confiança, o desejo da rainha estaria em segurança, pelo menos, por algum tempo. No entanto, não é o acontece aqui; a nutriz traiu a sua senhora. Esse é o próximo passo dos acontecimentos. Neste caso, é justamente a exposição por parte da aia a Hipólito do desejo amoroso de Fedra que leva tudo a perder, que carrega o que está mais escondido na esfera privada. É um ato equivocado realizado pela serva. Se Fedra temia que se propagasse um desejo oculto que residia em sua privacidade, agora, Hipólito revela algo que atinge um público que engloba não só a aia que está ali mas também Fedra e o coro que escutam a conversa por trás da porta, v. 565 ss. Como já se comentou anteriormente, Hipólito apresenta um discurso cheio de ódio contra as mulheres e contra os assuntos que envolvam os relacionamentos afetivos, chegando até a sugerir uma nova forma para o nascimento das crianças, como a ida a um templo a fim de retirá-la, v. 618 ss. O desejo de comprar um bebê no templo pode ter algum tipo de relação com o fato de que se consultava o oráculo para resolver problemas de esterilidade. ${ }^{19}$ Com esse tipo de proposta, a privacidade de um casal para gerar um filho nem estaria mais presente e o ato de geração de filhos se tornaria em algo público, pois não é necessário mais a dupla homem e mulher. A reação cheia de agressividade da parte de Hipólito fez com que Fedra julgasse que o seu desejo seria exposto de uma forma ou de outra. A seguir, a rainha escreve uma carta e se suicida, temendo que Hipólito torne público o seu desejo; no entanto, Fedra não sabe quem é realmente o filho de Teseu; conheceu somente um aspecto da personalidade do jovem, pois esse jurou que não falaria nada e, assim, cumpriu com a promessa mesmo que isso tenha custado a sua própria vida. Neste sentido, Hipólito defendeu o que é privado, respeitou o segredo de uma mulher mesmo a ameaçando. Valeu-se da sua pureza para salvar o desejo privado de uma mulher. Hipólito é um personagem que, de algum modo, compreende os riscos de um desejo particular que se torna público, no entanto, errou ao analisar a si mesmo, deixando que a sua opinião sobre Cípris alcançasse o âmbito público. Não importa se jurou que não denunciaria

${ }^{19}$ DEVEREUX, George. The character of the euripidean Hippolytos: an ethno-psychoanalytical, op. cit., p. 34. 
o segredo de Fedra; se ele compreende o binômio privado / público, não o consegue entender completamente quando ofendeu a deusa Afrodite.

A carta é praticamente o fim da privacidade da rainha. Nela o seu desejo aparece de modo invertido, pois é Hipólito quem seria o responsável pela desgraça da esposa de Teseu; é ele, o que não aprecia o contato amoroso, que teria ousado, e, com violência, teria tocado na rainha. Com a troca do privado pelo público da vida da rainha, Hipólito passa a ser o responsável direto pela destruição de Fedra e de si mesmo sem que saiba ainda o que está acontecendo. Mais do que nunca, Eurípides é um autor que questiona uma ética que se preocupa unicamente pelo exterior, pelas sanções sociais, pelas leis. ${ }^{20}$

Com sua chegada inesperada, de um lugar que resta desconhecido, Teseu adentra no palácio e, depois de ver a mulher morta, lê a carta. A sua chegada é triunfal, esperando receber o louvor de todos, isto é, não a realiza de modo secreto, por temer inimigos, como Héracles fez, ao entrar em uma cidade na peça homônima de Eurípides. Depois de saber a desgraça que desabava sobre a sua casa, Teseu, rapidamente, sem qualquer pudor, proclama que o filho havia tocado no seu leito. Um problema particular infunde terror na vida de Teseu e a comunidade agora sabe do ocorrido. Neste momento, privado e público não aparecem com algum tipo de distinção; fazem parte de uma única esfera com a qual os personagens dialogam, procurando atacar e se defender.

Eis a sutileza da situação construída por Eurípides, trata-se justamente de um engano em relação ao qual carta terá o maior crédito. É um documento íntimo que se torna público mesmo que seja falso. A rápida leitura de Teseu fez que o texto da carta fosse válido e sem qualquer tipo de questionamento e nem ao menos o rei de Trezena chama a aia de Fedra para indagar a respeito de sua veracidade, justamente a serva que principiou todo o processo da violação da privacidade de Fedra. Agora, para Teseu, basta o relato da carta e, na sua ótica, tudo está claro. A censura que se faz, aqui, contra a rapidez e outros erros grosseiros, é respalda por Ártemis no êxodo, quando critica a postura de Teseu, 1320-1324:

\footnotetext{
E tu, quanto àquele e a mim, revelas-te um perverso, que nem uma prova nem a palavra dos adivinhos esperaste, não questionaste, nem por um longo tempo permitiste um exame; contudo, com mais pressa do que tu devias, pronunciaste imprecações contra o teu filho e o mataste.
}

20 SEGAL, Charles. Shame and purity in Euripides'Hippolytus. Hermes, op. cit., p. 291. 
$\mathrm{Na}$ conversa entre pai e filho, depois que o primeiro retornou ao lar, há uma grande questão não só moral como retórica. Como se defender se não se pode falar do segredo mais terrível de alguém em relação a quem não se nutre amor mas só ódio? Como se defender, diante de todos que estão ali presentes, deixando claro que se é puro, que não se cometeu nenhum ato condenável, se não se pode desrespeitar um juramento? Como se defender se, para provar que é inocente, teria que se revelar um desejo que pertence ao universo privado de um indivíduo? Neste caso, um juramento a uma mulher que revelou algo tão íntimo de outra mulher. Em termos práticos, antes da conversa iniciar, o pai de Hipólito já o amaldiçoou; já o julgou e o lançou à morte. Faz tudo publicamente, isto é, não há chances para Hipólito, de qualquer forma, mesmo que empregasse as melhores provas. O filho entrou em um debate já perdendo, pois foi prejulgado. Além do que a vida de Hipólito sofre uma devassa, pois até a alimentação padece de crítica, v. 952-953. É o momento do acerto de contas, visto que tudo vem à tona contra o filho de Teseu. Tudo é realizado no âmbito público. Não se trata de uma conversa reservada.

O rei de Trezena, cidade desta tragédia, deve demonstrar bons exemplos ao seu povo. É o que se observa pelo comportamento de outros reis, como, por exemplo, Agamêmnon, na tragédia homônima, de Ésquilo; o próprio Teseu em Édipo em Colono, de Sófocles; Édipo no Édipo Rei, também de Sófocles, e os exemplos se estenderiam. Aquilo que o rei faz se torna público, se transforma em exemplo, pois ele possui uma legitimidade, muitas vezes, por sua sabedoria, pela sua genealogia e por outros atributos. Aqui, temos um dos poucos casos registrados nas tragédias nas quais o rei se comporta de modo desastroso.

Se já havia julgado Hipólito, sem antes ouvi-lo, empregou uma das imprecações que lhe foi dada pelo deus Posídon, conforme a informação dada por Afrodite no prólogo. É o pai ausente que julga o filho, sem verificar diversas possibilidades de um suicídio por parte de Fedra. Nem aos adivinhos consultou, conforme Ártemis o questionou. A sua imagem de pai e legislador é, a partir de agora, severamente questionada. O exílio dado a Hipólito se constitui em um recurso público para resolver rapidamente uma situação familiar dentro de um espaço público.

Lá longe Hipólito sofre o ataque do touro e tudo se desenvolve em um espaço público mas fora da cidade. ${ }^{21} \mathrm{~A}$ incapacidade da compreensão de algo

${ }^{21}$ SEGAL, Charles. Theatre, ritual and commemoration in Euripides'Hippolytus. Ramus, op. cit., p. 61 . 
tão privado como foi o desejo de Fedra contribuiu nesse desfecho trágico. Agora, com a morte do jovem, Charles Segal ${ }^{22}$ assinala que os espaços existentes entre público e privado, além da dupla homem e mulher, estão se fechando. O referido helenista diz também que Hipólito retorna ao palco como objeto de interesse público, v. 1157-9, "Teseu, carrego uma notícia digna de preocupação / para ti e para os cidadãos que habitam a cidade de Atenas / e os limites da terra de Trezena". Além do sofrimento comum a todos que agora é evidente, v. 1461-2, "Esta dor, comum a todos os cidadãos, / chegou, de modo imprevisto". Por fim, Charles Segal comenta que o lamento cívico dentro desse espaço substitui o lamento privado de Teseu por Fedra. ${ }^{23}$

A situação da tragédia atinge o clímax e o espaço privado fica de lado, deixando que a esfera pública domine o resto da peça. Ainda segundo Charles Segal, o final da peça reflete uma concepção da comunidade destacada pelo teatro e a forma pela qual a tragédia compreende o sofrimento no âmbito da vida privada e da compreensão da cidade como um todo. ${ }^{24}$ Em outro contraponto, o desastre de Teseu se aproxima do personagem Édipo, da peça Édipo Rei, de Sófocles, cuja vida privada, que não conhecia plenamente, foi revelada de tal modo que o conhecimento que mantinha de si mesmo era ilusório. Teseu não perde o comando de Trezena, mas Édipo se afasta de Tebas, pelos atos que praticou.

Desta forma, a tragédia consegue envolver cenas de lamento e transforma o sofrimento privado em espetáculo público. ${ }^{25}$ Barbara Goff destaca que também "... a peça pode ser lida como uma série de tentativas para silenciar um desejo que continuamente irrompe dentro da mais destrutiva fala." 26 Neste caso, toda a vez que o desejo de Fedra por Hipólito veio à tona, é respondido da pior forma possível, como se observa nas respostas da aia, de Hipólito e de Ártemis. A esposa de Teseu é pouco compreendida e o resultado desses posicionamentos repercutem nas vidas que são perdidas à medida que tudo aquilo que pertence ao privado alcança o público.

O término da tragédia alcança um outro ápice e a ironia está presente. Nem Teseu nem o coro perceberam o que, de fato, aconteceu, quando Hipólito, conforme já destacamos, perpetuará o seu nome na cidade, v. 1423-

\footnotetext{
22 Ibidem, p. 58 ss.

23 Ibidem.

${ }^{24}$ Ibidem, p. 54.

25 Ibidem, p. 55 ss.

${ }^{26}$ GOFF, E. Barbara. The noose of words: readings of desire, violence \& language in Euripides' Hippolytos. Cambridge: Cambridge University Press, 1996, p. 105.
} 
30, em um rito que envolve não só Fedra mas também o matrimônio. ${ }^{27} \mathrm{O}$ espectador da peça está ciente desse contraponto que é instaurado a partir desse momento.

Assim, nesse binômio entre privado e público, observamos a dinâmica que reside nessa combinação ao longo do texto de Eurípides. A cadência é a marca de todo esse processo, pois gradativamente o desejo oculto da rainha se revela, saindo dos seus pensamentos até alcançar todos os habitantes da cidade de Trezena. O desejo erótico contido no ambiente privado, que abarca o fechado, o proibido e o que é oculto se torna inoperante, termina por ser revelado. A tentativa de bloquear uma paixão e a falta de compreensão desse sentimento foram decisivos para o desastre da família de Teseu. Cada um dos personagens soube, em determinados momentos da peça, o segredo de Fedra, cada um a sua maneira o compreendeu. Se a aia, que sabia do segredo, perdeu a sua senhora, no caso de Hipólito, que sabia de tudo, terminou perdendo a sua própria vida. Teseu, que só sabia parte da verdade, contribui para a perdição de seu filho. Há, sem dúvida, uma profunda relação entre conhecer ou não o desejo da rainha com a perda do privado que se torna público.

27 SEGAL, Charles. Theatre, ritual and commemoration in Euripides'Hippolytus. Ramus, op. cit., p. 55. 